\title{
FACTORS AFFECTING EMPLOYEE'S AWARENESS OF THEIR IMPACT ON CORPORATE REPUTATION
}

\author{
Dindha Vitri Primadini \\ Faculty of Economics and Business, Universitas Indonesia \\ dindha.vitri@ui.ac.id \\ Muhammad Irfan Syaebani \\ Faculty of Economics and Business, Universitas Indonesia \\ muhammad.irfan11@ui.ac.id
}

\begin{abstract}
This study examines factors that affect employees' awareness of their impact on corporate reputation (AICR). We distribute our questionnaire to 161 employees of Indonesian state-owned enterprises (SOEs) as our sample. Our main findings show that both perceived corporate reputation (PCR) and affective commitment positively affect AICR with PCR exhibits the greatest effect. It then can be concluded that building a good corporate reputation is the most effective way to increase employees' AICR.
\end{abstract}

Keywords: corporate reputation, affective commitment.

\begin{abstract}
ABSTRAK
Penelitian ini mengkaji faktor-faktor yang memengaruhi kesadaran karyawan bahwa tindakan mereka dapat memengaruhi reputasi perusahaan yang bergerak di bidang pelayanan milik pemerintah Indonesia. 161 kuesioner dianalisis menggunakan metode penelitian kuantitatif. Temuan utamanya adalah bahwa kesadaran karyawan bahwa tindakan mereka dapat memengaruhi reputasi perusahaan dipengaruhi secara langsung oleh seberapa bagus persepsi karyawan terhadap reputasi perusahaan tersebut dan komitmen afektif mereka terhadap perusahaan. Namun demikian, pengujian terhadap model menyatakan bahwa persepsi karyawan terhadap reputasi perusahaan memiliki pengaruh terbesar terhadap kesadaran karyawan, oleh karena itu disimpulkan bahwa cara efektif dalam meningkatkan kesadaran mereka adalah dengan membangun reputasi perusahaan yang bagus.
\end{abstract}

Kata Kunci: reputasi perusahaan, komitmen afektif.

\section{INTRODUCTION}

Corporate reputation is a critical intangible asset for a company to achieve its goals. It is an assessment of company's past performance (Fombrun and Riel 1997) and is a result of all people within the company (Cravens and Oliver 2006). Arikan et al. (2016) said that company needs to leverage the perception with the aim to build competitive advantage since today's environment is highly volatile. Thus, in a service 
company, corporate reputation could be shaped by the employees through their interaction with the consumer.

For a state-owned company, corporate reputation is critical to improve society's perception towards company and government in a country. It is a strategic instrument for the government to increase society's well being and economic growth (Barnett et al., 2006). Moreover, Li et al. (2016) found out that corporate reputation has significant positive relationship with corporate growth. This growth is required since state-owned company does not only seek for profit but also serves for society's well being. Many of state-owned companies are granted monopoly which means if their performance is poor it will affect to society directly. Thus, employee's awareness has a pivotal role to the corporate reputation because in services company people are the key for delivering value.

This study emphasizes on employee's role in creating corporate reputation by analyzing how the employee's feeling for their job and organization. The awareness of employee's impact on corporate reputation (AICR) has to be built since the employee represents the company objectives, values, and strategies (Cravens and Oliver 2006). This research becomes important because as Levia et al. (2016) said that corporate reputation has become crucial topic but it is least discussed and it had not been measured properly especially in the business ethic field. Therefore, it is very urgent to examine and understand the relationship between corporate reputations with employee's behavior. Cervellon and Lirio (2017) said that company encourages employee to become brand ambassador to the customer, but they found out that many employees are in reality still cannot fulfill this role. It becomes the research gap to fill on how employee's role in shaping corporate reputation based on employee's feeling toward the organization. It means employee plays the role in shaping corporate reputation but it is still unclear of what factors are exactly contributed to corporate reputation from employee's feeling or in this research it refers as employee's awareness of their impact on corporate reputation or AICR.

\section{LITERATURE REVIEW}

\section{Perceived Corporate Reputation}

According to Barnett et al. (2006), corporate reputation could be seen in three forms; awareness, assessment, and asset. As awareness, corporate reputation is a perception of stakeholders which indicates their recognition to the company. As assessment, corporate reputation is a result of evaluation or measurement to company's status whether it is good or bad. While as asset, corporate reputation is a company's resource.

Olmedo-Cifuentes et al. (2013) argued that corporate reputation could be affected by quality of leadership, business strategy, and ethics showed by organization. Corporate culture also can affect company's image in the eyes of its employees (Gotsi 
and Wilson 2001). Perception to corporate reputation which is posed by employees can impact their loyalty to the company. Corporate reputation can also affect employee's behavior in organization (Davies et al., 2004).

\section{Pride}

Following Tracy and Robins (2007), pride occurs when a person succeed in achieving something. Opinion of others may contribute in forming the pride; this opinion may serve as recognition that the person has capabilities (Arnett et al., 2002). Verbeke et al. (2004) stated that pride is a result of positive evaluation from significant others to the person. In organization, pride is determined by job clarity, job challenge, organization goal, organization performance, work enjoyment, reward and recognition, and training adequacy (Gunter and Furnham 1996).

\section{Organizational Commitment}

Organizational commitment is reflection of positive affection from a person to organization and its values (Boles et al., 2007). Organizational commitment is characterized by three features: strong belief to organization values and goals, willingness to give effort for the sake of organization, and willingness to maintain membership in organization (Mowday and Steers 1979).

In this research, affective commitment is the main focus of organizational commitment. Many scholars said that affective commitment is the strongest predictor which makes employee stays in organization and employee with high level of affective commitment is more likely to exercise extra effort to achieve organizational goals compare to employee with low level of affective commitment.

\section{Job Satisfaction}

Organization needs to maintain employee's job satisfaction because job satisfaction indicates to affect various behaviors exhibited by employee at the workplace (Boles et al., 2007). Employee with high level of job satisfaction tends to be more productive and shows more effective performance (Robbins and Judge 2015). Besides, when organization is in crises the probability of employee leaving organization is lower when he/she has high level of job satisfaction (Hamermesh 2001). The employee will have impression that showing good behavior might be rewarded by organization (Arnett et al., 2002) thus in service organization, satisfied employee can increase his/her loyalty and in the end will affect to customer satisfaction (Robbins and Judge 2015).

\section{Employee's Awareness of Their Impact on Corporate Reputation (AICR)}

Kennedy (1997) in Gotsi and Wilson (2001) might be considered as the first researchers who emphasized and proved that organization member is not just a person working in organization but also simultaneously can build corporate image to stakeholders. Employee as member of organization represents goals, values, and strategies where he/she works (Cravens and Oliver 2006). Employee, when interacts 
with customers, will contribute to shape the image of the company through the behaviors he/she exhibits during service process.

Member of organization when giving comment to place where he/she works might impact on how corporate reputation is perceived by society later on. If the member of organization has good comment to the organization then this good perception will be disseminated or be communicated to public by the employee. AICR is defined as feeling of responsibility from employee which realized that their behavior may affect reputation of organization and to increase the AICR organization needs to internalize it through corporate culture. Communication also must be prioritized in organization to emphasize the importance of corporate image in order to achieve organization goals (Cravens and Oliver 2006).

\section{Hypotheses Formulation}

Ettenson and Knowles (2008) explained reputation as a concept of organization credibility in the eye of stakeholder. It could be its employee, consumer, investor, policy maker, journalist, or local community. For employees, corporate reputation affects how they perceive the company (Davies et al., 2004). A good corporate reputation leads to employee's self efficacy (Carmeli 2004) and safeguard the company at times of crises (Shamma 2012). Yet a bad reputation leads to employee's depression and stress because of negative comments of other people (Dutton et al., 1994).

According to Tracy and Robins (2007), one of the basic human emotions is a positive feeling which occurred as people achieve something meaningful, which is called by pride. In the organization, pride and loyalty could be affected by organizational identification (Ashforth and Mael 1989), which is a process by which people classifying themselves into social categories. Here people focused to define themselves and to be defined by other people as a member of a group (Tajfel and Turner 1986). Pride is crucial because it stimulates motivations related to performance can (Verbeke et al., 2004). Arnett et al. (2002) found that higher pride leads to the employee's perception of organization as something important, meaningful, and effective.

Another employee's positive feeling towards organization and its values is organizational commitment (Boles et al., 2007). Organizational commitment is characterized by the strong belief of organizations goals and values, willingness to do extra effort for organization, and desire to stay or maintain the membership (Mowday and Steers 1979). This study uses affective component of commitment which is defined as emotional attachment of employees towards organization. Those who have affective commitment decide to stay because they want to. They enjoy their membership in organization (Allen and Meyer 1990). After complete the work, they evaluate their job thereafter. This evaluation will lead to job satisfaction (Arnett et al., 
2002). High job satisfaction shows positive feeling which employees have to their job (Robbins and Judge 2015).

Being a part of reputable companies increases employee's self efficacy (Carmeli 2004). Helm (2011) added that it also could build pride within employees. The study's first hypothesis therefore suggest,

H1: Perceived corporate reputation has a positive impact on employee's pride.

Perceived corporate reputation is a form of evaluation by employees towards company's reputation. It could be related to job satisfaction which is an overall evaluation of a job (Arnett et al., 2002).

Helm (2011) found out that there are positive relationship between corporate reputation and job satisfaction. Moreover, Dolatabadi et al. (2012) also argued good employee's perception to organization is one of positive aspect when determining employees evaluation through their job. Thus, the second hypothesis therefore suggest,

H2: Perceived corporate reputation has a positive impact on employee's job satisfaction.

Working in a reputable company can also create emotional attachment between employees and the company (Cable and Turban 2003). Emotional attachment according to Allen and Meyer (1990) is affective component of organizational commitment.

According to Helm (2011), perception of corporate reputation can impact to employees' loyalty. Good corporate perception will make employees more enthusiastic in appraising their working environment and make them more attached to organization. Thus, the third hypothesis therefore suggest,

H3: Perceived corporate reputation has a positive impact on employee's affective commitment.

According to the Social Identity Theory, people tend to classify themselves into a distinctive and amore unique group from others (Ashforth and Mael 1989). In this study, group distinctiveness and uniqueness are defined as the same with corporate reputation. The more employees classify themselves towards a company; they tend to support the company (Ashforth and Mael 1989) or it refers to Employee's awareness of their impact on corporate reputation or AICR. The fourth hypothesis therefore suggest,

H4: Perceived corporate reputation has a positive impact on AICR.

Arnett et al. (2002) suggest that higher pride leads to perception of organization as something important, meaningful and effective. Employees are more likely to help company to achieve its objective. The fifth hypothesis therefore suggest,

H5: Employee's pride has a positive impact on affective commitment. 
For employees, working in a company that brings pride to them is more satisfying than work in company which could not bring any pride at all. The pride leads employees to engage more in company activities (Helm 2011). This leads to the sixth and seventh hypothesis,

H6: Employee's pride has a positive impact on job satisfaction.

H7: Employee's pride has a positive impact on AICR.

Meyer et al. (2002) stated that job satisfaction has a strong correlation with affective commitment. The past study shows that job satisfaction is the one that causes affective commitment because it is more specific, unstable, and quickly shaped (MacKenzie et al., 1998).The eighth hypothesis therefore suggest,

H8: Job satisfaction has a positive impact on affective commitment.

Employee's evaluation towards their job is made up by the job components such as the job itself (daily responsibilities), co-worker, supervisor, salary, and the others (Nagy 2002). The more positive feeling resulted from that evaluation indicating the higher employee's job satisfaction. Job satisfaction has a vital role in encouraging the employees to behave as desired by the organization (Arnett et al., 2002). The ninth hypothesis therefore suggest,

H9: Job satisfaction has a positive impact on AICR.

Affective commitment shows employee's attachment with the company and their willingness to maintain membership (Allen and Meyer 1990). Commitment is also characterized by a person's willingness to make efforts on behalf of the organization (Ashforth and Mael 1989). The tenth hypothesis therefore suggest,

H10: Affective commitment has a positive impact on AICR.

The theoretical model in this study is adapted from Sabrina Helm's study on 2011 titled Employee's awareness of their impact on corporate reputation. Employee's awareness of their impact on corporate reputation will be symbolized as AICR, perceived corporate reputation as PCR, pride as $\mathrm{P}$, affective commitment as $\mathrm{AC}$, and job satisfaction as JS. 


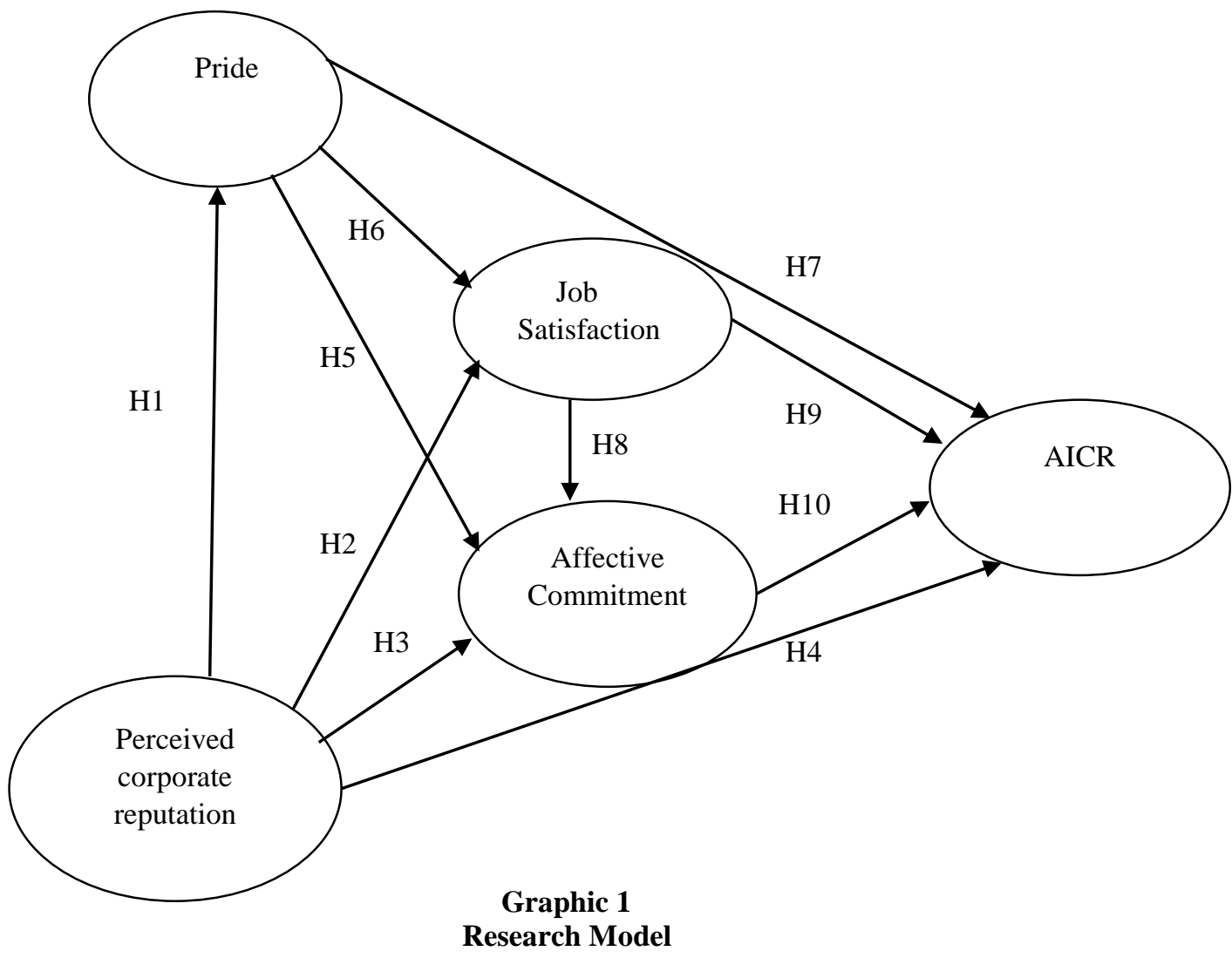

\section{RESEARCH METHOD}

AICR is defined as feeling of responsibility from employee which realized that their behavior may affect reputation of organization where they work. In this research AICR is measured using measurement formulated by Helm in 2011. PCR is defined as an image perceived by many people to organization and it is measured using tool formulated by Fortune in 2008. P is defined as a form of emotion as a result of self evaluation which reflected in employee's feeling that organization is inseparable from their life. P is measured using measurement formulated by Cable and Turban in 2003. $\mathrm{AC}$ is defined as positive feeling from employee to organization and values in organization and it is measured using tool built by Allen and Meyer in 1990. JS is defined as positive feeling as a result of evaluation to job and measured using Job Description Index measurement.

The data is gathered by distributing 161 questionnaires to the employees of a state-owned company in Indonesia using non-probability sampling technique and six point likert scales is used to reduce central tendency of respondent's response. Thereafter the data is processed using Structural Equation Modeling (Lisrel 851 software). Maholtra and Birks (2007) explained that the purpose of validity test is to measure the extent of measurement tool could represent the characteristic of observed phenomenon. It is valid if the $t$-value of each variable $\geq 1.645$ and the standardized 
loading factor (SLF) $(\mathrm{SLF}) \geq 0.5$. Reliability test is carried out afterwards, which measures the extent to which the measurement reproduces consistent result. It is showed by variance extracted $(\mathrm{VE}) \geq 0.5$ and construct reliability $(\mathrm{CR}) \geq 0.7$. The last, the hypotheses are tested through the structural model testing.

\section{RESULTS AND DISCUSSION}

Table 1 shows that all variables are valid. The reliability test of perceived corporate reputation, pride, affective commitment, and job satisfaction are good yet the AICR has 0.33 VE value. But VE is a more conservative measurement according to Maholtra (2010). Thus AICR variable could be considered as reliable even though the VE is less than 0.5 .

Table 2 presents that perceived corporate reputation has a positive impact on pride, job satisfaction, and AICR. It means that a good quality of top level management and product could increase feeling of pride to the company, satisfaction on coworker and job promotion, and employee's responsibility to guard the company's reputation (supporting $\mathrm{H} 1, \mathrm{H} 2$, and $\mathrm{H} 4$ ). While affective commitment is not positively affected by how employees think about the company (rejected H3).

Employee's pride positively affects affective commitment and job satisfaction. In this study, the characteristic of company is a monopolist which operates to implement constitutional order. This fact leads to the willingness of employees to spend their rest of career in this company as a sense of benevolence by serving the society (supporting H5). It also increases employee's job satisfaction as explained by Maslow's Hierarchy of Needs in which people have esteem needs (Westover 2011). Hence it could be concluded that employee's need of esteem could be fulfilled (high job satisfaction) when other people associate themselves with the company (supporting H6). Pride has insignificant effect towards AICR indicating that the more employee feel of pride of the company does not automatically increase their feeling of responsibility to the corporate reputation (rejected H7). It is because of the company's monopolistic characteristic which society has no other choices to buy the product from another competitor. 
Table 1

Validity and Reliability Result

\begin{tabular}{|c|c|c|c|c|c|}
\hline Item & Variable & t-value & SLF & $\mathbf{C R}$ & VE \\
\hline PCR & \multicolumn{3}{|c|}{ Perceived Corporate Reputation } & 0.96 & 0.74 \\
\hline PCR1 & Quality of top management & 2.57 & 0.83 & & \\
\hline PCR2 & Quality of product & 3.09 & 0.85 & & \\
\hline PCR3 & Innovation & 0.74 & 0.74 & & \\
\hline PCR4 & $\begin{array}{l}\text { Ability to attract and manage talented } \\
\text { employees }\end{array}$ & 1.42 & 0.77 & & \\
\hline PCR5 & Wise use of corporate assets & 1.22 & 0.76 & & \\
\hline PCR6 & Social and environmental Responsibility & 1.67 & 0.79 & & \\
\hline PCR7 & Financial soundness & 0.19 & 0.71 & & \\
\hline PCR8 & Long term investment & 2.50 & 0.82 & & \\
\hline PCR9 & Globalness & 9.45 & 0.68 & & \\
\hline $\mathbf{P}$ & \multicolumn{3}{|l|}{ Pride } & $\mathbf{0 . 8 3}$ & 0.61 \\
\hline $\mathrm{P} 1$ & Proud to be part of the company & 9.91 & 0.72 & & \\
\hline $\mathrm{P} 2$ & $\begin{array}{l}\text { Proud when people associate me with the } \\
\text { company }\end{array}$ & 12.95 & 0.88 & & \\
\hline P3 & $\begin{array}{l}\text { Proud to tell others that I work for this } \\
\text { company }\end{array}$ & 10.35 & 0.74 & & \\
\hline $\mathbf{A C}$ & \multicolumn{3}{|c|}{ Affective Commitment } & 0.89 & 0.5 \\
\hline $\mathrm{AC} 1$ & Really care about company's fate & 8.08 & 0.61 & & \\
\hline $\mathrm{AC} 2$ & $\begin{array}{l}\text { Importance of working towards company's } \\
\text { objective }\end{array}$ & 11.90 & 0.81 & & \\
\hline $\mathrm{AC} 3$ & $\begin{array}{l}\text { Very happy to spend the rest of career in this } \\
\text { company }\end{array}$ & 12.01 & 0.80 & & \\
\hline $\mathrm{AC} 4$ & It is the best company to work & 8.07 & 0.61 & & \\
\hline AC5 & Sense of belongingness to the company & 8.07 & 0.61 & & \\
\hline AC6 & The company has a personal meaning for me & 11.07 & 0.76 & & \\
\hline $\mathrm{AC7}$ & $\begin{array}{l}\text { Willingness to do extra effort for company's } \\
\text { success }\end{array}$ & 11.43 & 0.78 & & \\
\hline $\mathrm{AC} 8$ & Similarity of personal and company's values & 9.89 & 0.70 & & \\
\hline $\mathbf{J S}$ & \multicolumn{3}{|l|}{ Job Satisfaction } & 0.89 & 0.55 \\
\hline JS1 & Salary & 6.91 & 0.53 & & \\
\hline $\mathrm{JS} 2$ & Working tasks & 10.59 & 0.74 & & \\
\hline JS3 & Job promotion & 12.52 & 0.84 & & \\
\hline JS4 & Advancement opportunities & 12.92 & 0.86 & & \\
\hline JS5 & Coworker & 9.57 & 0.69 & & \\
\hline JS6 & Supervisor & 10.07 & 0.72 & & \\
\hline JS7 & Quality of top level management & 10.90 & 0.76 & & \\
\hline AICR & \multicolumn{3}{|c|}{ Awareness of Employee's Impact on Corporate Reputation } & 0.71 & 0.33 \\
\hline AICR1 & $\begin{array}{l}\text { Awareness that each employees can } \\
\text { contribute to corporate reputation }\end{array}$ & 6.97 & 0.56 & & \\
\hline AICR2 & $\begin{array}{l}\text { Knowing how to influence corporate } \\
\text { reputation }\end{array}$ & 6.16 & 0.50 & & \\
\hline AICR3 & $\begin{array}{l}\text { Significance of employee's personal doing } \\
\text { towards corporate reputation }\end{array}$ & 6.43 & 0.52 & & \\
\hline AICR4 & Feeling like company's ambassador & 6.50 & 0.52 & & \\
\hline AICR5 & Feeling responsible for corporate reputation & 9.86 & 0.74 & & \\
\hline
\end{tabular}


Table 2

Information on the Structural Model

\begin{tabular}{llrl}
\hline Hypothesis & \multicolumn{1}{c}{ Path } & t-value & \multicolumn{1}{c}{ Result } \\
\hline H1 & PCR $\rightarrow$ Pride & 4.73 & Significant \\
H2 & PCR $\rightarrow$ Job satisfaction & 3.81 & Significant \\
H3 & PCR $\rightarrow$ Affective commitment & 0.25 & Insignificant \\
H4 & PCR $\rightarrow$ AICR & 1.87 & Significant \\
H5 & Pride $\rightarrow$ Affective commitment & 4.84 & Significant \\
H6 & Pride $\rightarrow$ Job satisfaction & 4.07 & Significant \\
H7 & Pride $\rightarrow$ AICR & 0.40 & Insignificant \\
H8 & Job satisfaction $\rightarrow$ Affective commitment & 3.51 & Significant \\
H9 & Job satisfaction $\rightarrow$ AICR & -0.81 & insignificant \\
H10 & Affective commitment $\rightarrow$ AICR & 4.67 & Significant \\
\hline
\end{tabular}

Table 3

Path to AICR

\begin{tabular}{ll}
\hline \multicolumn{1}{c}{ Path } & Effect \\
\hline PCR $\rightarrow$ AICR & 0.16 \\
PCR $\rightarrow$ Pride $\rightarrow$ Job satisfaction $\rightarrow$ Affective commitment $\rightarrow$ AICR & 0.02 \\
PCR $\rightarrow$ Pride $\rightarrow$ Affective commitment $\rightarrow$ AICR & 0.07 \\
PCR $\rightarrow$ Job satisfaction $\rightarrow$ Affective commitment $\rightarrow$ AICR & 0.10 \\
\hline
\end{tabular}

Employee's job satisfaction in this study does not have a positive impact on AICR (dismissing H9) yet has a positive impact on the willingness to stay in the company (supporting H8). Perry and Wise (1990) explained that there are three needs that public sector employees commonly posses. The first is rational motive which is motivation of employees to participate in a policy making activities, identified with society's program, and to pursue their personal interest. The second is norm-based motive: the desire to serve public interest and the third is affective motives: willingness to commit towards a program because of its social importance. Finally, as employees decided to stay within the company, it could increase their AICR (supporting H10).

After the hypotheses are tested, the path is being analyzed to shows the ways to affect the employee's awareness of their impact to corporate reputation. Table 3 presents that the employee's awareness of their impact on corporate reputation through four paths. The first path is the most effective path, which has the strongest effect.

Corporate reputation is important to employee, because corporate reputation could be utilized by organization to make them engage to the organization. Good corporate reputation will lead to the feeling of inseparable between employee and organization because employee feels that organization is the part of his/her personal life. This research is in accordance with statement of Riordan et al. (1997) who emphasized that corporate reputation will affect work attitude of employees. Moreover, Haque (2001) stated that in public sector organization, employee's pride is source of motivation to serve and deliver service excellent to customer. 


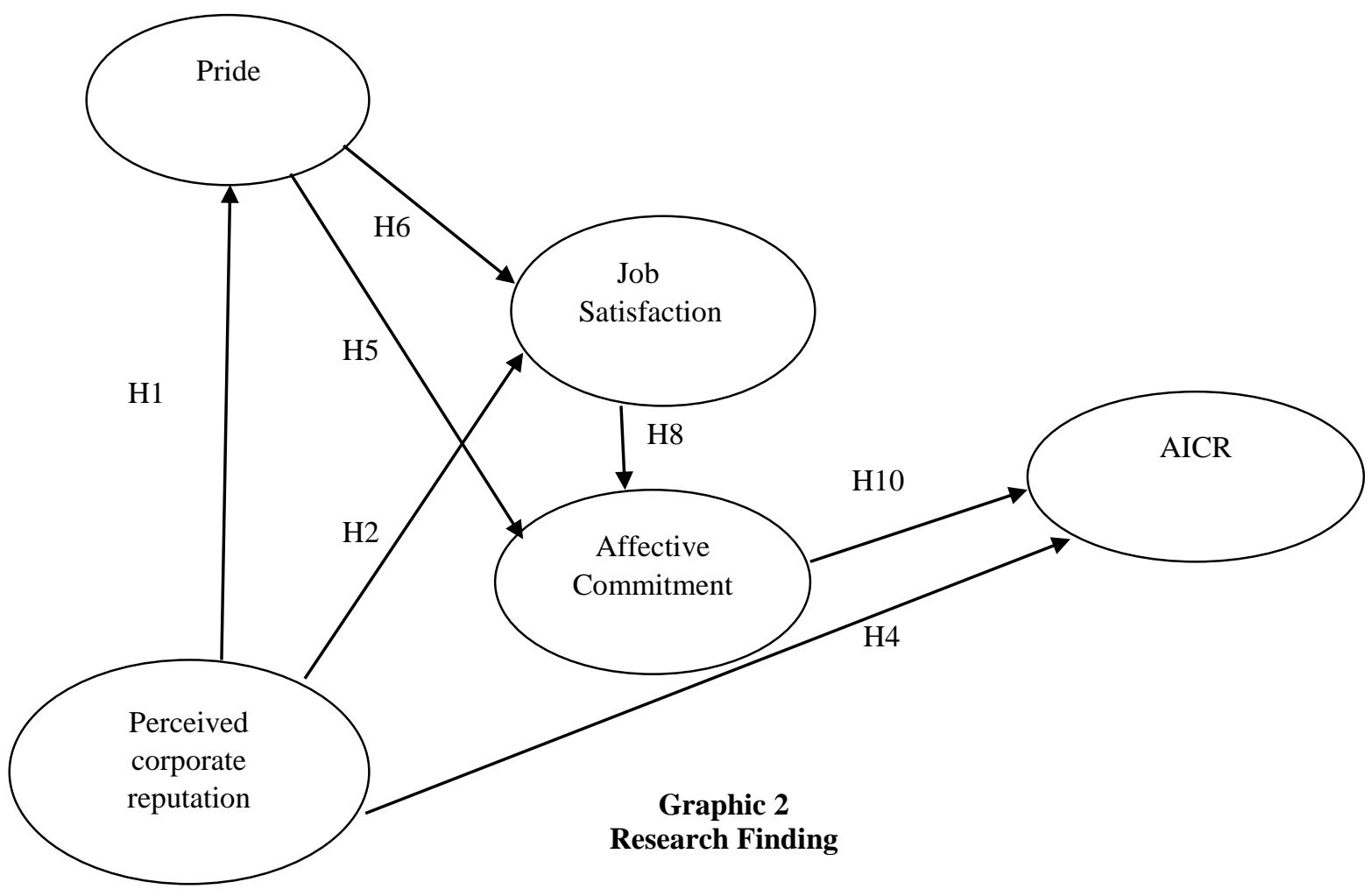

\section{CONCLUSION, LIMITATION AND SUGGESTION}

Based on this finding, to increase the employee's awareness of their impact on corporate reputation, the manager has to focus on building a good corporate reputation for the employees. The top three strategies which are effective to be done are improving the quality of products and top management, increasing the long term investment, social and environment responsibility, and improving the ability to attract and manage the talented employees.

This research only focused to one company as a case study. Therefore, the result might not represent all the organizations in Indonesia in general since not all industries are covered. The research also chose state-owned company as a subject which is different in nature with private companies. Thus, in the future researcher must consider various organizations to confirm that the conclusion could be applied to many organizations in different context. 


\section{REFERENCES}

Allen, N. J., and J. P. Meyer. 1990. "Measurement and antecedents of affective, continuance, and normative commitment to the organization". Journal of Occupational Psychology 63(1): 1-18.

Arikan, E., D. Kantur, C. Maden, and E. E. Telci. 2016. "Investigating the mediating role of corporate reputation on the relationship between corporate social responsibility and multiple stakeholder outcomes". Quality and Quantity 50(1): 129-149.

Arnett, D. B., D. A. Laverie, and C. McLane. 2002. "Using job satisfaction and pride as internal-marketing tools". Cornell Hotel and Restaurant Administration Quarterly 43(2): 87-96.

Ashforth, B., and F. Mael. 1989. "Social identity theory and the organization". The Academy of Management Review 14(1): 20-39.

Barnett, M. L., J. M. Jermier, and B. A. Lafferty. 2006. "Corporate reputation: The definitional landscape". Corporate Reputation Review 9(1): 26-38.

Boles, J., R. Madupalli, B. Rutherford, and J. A. Wood. 2007. "The relationship of facets of salesperson job satisfaction with affective organizational commitment". Journal of Business and Industrial Marketing 22(5): 311-321.

Cable, D. M., and D. B. Turban. 2003. "The value of organizational reputation in the recruitment context: A brand-equity perspective". Journal of Applied Social Psychology 33(11): 2244-2266.

Carmeli, A. 2004. "The link between organizational elements, perceived external prestige and performance". Corporate Reputation Review 8(1): 314-331.

Cervellon, M. C., and P. Lirio. 2016. "When employees don't 'like' their employers on social media”. MIT Sloan Management Review 52(2): 63-70.

Cravens, K., and E. Oliver. 2006. "Employees: The key link to corporate reputation management”. Business Horizons 49: 293-302.

Davies, G., R. Chun, R. V. Silva, and S. Roper. 2004. "A corporate character scale to assess employees and customer views of organization reputation". Corporate Reputation Review 7(2): 125-146.

Dolatabadi, H. R., T. Ghujali, and M. Shahmohammadi. 2012. "Analysis of employee's awareness from their manner of impact on the organizational reputation”. International Journal of Business and Social Science 3(3): 220228.

Dutton, J. E., J. M. Dukerich, and C. V. Harquail. 1994. "Organizational images and member identification". Administrative Science Quarterly 39(2): 293-263. 
Ettenson, R., and J. Knowles. 2008. "Don't confuse corporate reputation with brand". MIT Sloan Manage Review 49(2): 19-21.

Fombrun, C., and C. V. Riel. 1997. "The reputational landscape". Corporate Reputation Review 1: 5-13.

Gotsi, M., and A. Wilson. 2001. "Corporate reputation management: "Living the Brand"”. Management Decision 39(2): 99-104.

Gunter, B., and A. Furnham. 1996. "Biographical and climate predictors of job satisfaction and pride in organization”. Journal of Psychology 130(2): 193-208.

Hamermesh, D. S. 2001. 'The changing distribution of job satisfaction”. The Journal of Human Resources 36(1): 1-31.

Haque. 2001. "Pride and performance in the public service: Three Asian cases". International Review of Administrative Sciences 67(1): 99-115.

Helm, S. 2011. "Employees' awareness of their impact on corporate reputation". Journal of Business Research 64(7): 657-663.

Levia, R., I. Ferrero, and R. Calderon. 2016. "Corporate reputation in the business ethics field: Its relation with corporate identity, corporate image, and corporate social responsibility”. Corporate Reputation Review 19(4): 299-315.

Li, H.G., Z. W. Chen, and G. X. Ma. 2016. "Corporate reputation and performance”. Entrepreneurial Business and Economics Review 4(3): 181-193.

MacKenzie, S. B., P. M. Podsakoff, and M. Ahearne. 1998. "Some possible antecedents and consequences of in-role and extra-role salesperson performance". Journal of Marketing 62(3): 87-98.

Maholtra, N. K. 2010. “Marketing research: An applied orientation”. Upper Saddle River, NJ: Pearson.

Maholtra, N. K., and D. F. Birks. 2007. "Marketing research: An applied approach”, $3^{\text {th }}$ edition, Milan: Pearson Prentice Hall.

Meyer, J. P., D. J. Stanley, L. Herscovitch, and L. Topolnytsky. 2002. “Affective, continuance, and normative commitment to the organization: A meta-analysis of antecedents, correlates, and consequences". Journal of Vocational Behavior 61: 20-52.

Mowday, R. T., and R. Steers. 1979. "The measurement of organizational commitment". Journal of Vocational Behavior 14: 224-247.

Nagy, M. S. 2002. "Using a single-item approach to measure facet job satisfaction". Journal of Occupational and Organizational Psychology 75(1): 77-86.

Olmedo-Cifuentes, I., I. M. Martinez-Leon, and G. Davies. 2013. "Managing internal stakeholders' views of corporate reputation”. Empirical Article 8(1): 83-111. 
Perry, J. L., and L. R. Wise. 1990. "The motivational bases of public service". Public Administration Review 50(3): 367-373.

Riordan, C. M., R. D. Gatewood, and J. B. Bill. 1997. "Corporate image: Employee reactions and implications for managing corporate social performance". Journal of Business Ethics 16(4): 401-412.

Robbins, S. P., and T. A. Judge. 2015."Organizational behavior”, $16^{\text {th }}$ edition, New Jersey: Pearson Prentice Hall.

Shamma, H. M. 2012. "Toward a comprehensive understanding of corporate reputation: Concept, measurement and implications". International Journal of Business and Management 7(16): 151-169.

Tajfel, H., and J. C. Turner. 1986. "The social identity theory of intergroup behavior". Psychology of Intergroup Relations 5: 7-24.

Tracy, J., and R. Robins. 2007. "Emerging insight into the nature and function of pride". Current Direction in Psychological Science 16(3): 147-150.

Verbeke, W., F. Belschak, and R. P. Bagozzi. 2004. "The adaptive consequences of pride in personal selling”. Journal of the Academy of Marketing Science 32(4): 386-402.

Westover, J. H. 2011. "Examining job satisfaction: Causes, outcomes, and comparative differences". Common Ground Publication (JHW). 